\title{
Impact of Weather on Sigatoka Leaf Spot of Banana (Musa spp. L.) and its Ecofriendly Management
}

\author{
M. A. H. Khan ${ }^{1}$, I. Hossain ${ }^{2}$ and M. U. Ahmad ${ }^{2}$ \\ ${ }^{1}$ On-Farm Research Division, Bangladesh Agricultural Research Institute, Gazipur; ${ }^{2}$ Department of \\ Plant Pathology, Bangladesh Agricultural University, Mymensingh, Bangladesh \\ *Corresponding author and Email: helim1367@yahoo.com
}

Received: 18 August 2015

Accepted: 12 December 2015

\begin{abstract}
A study was carried out during July 2010 to April 2012 to understand the effect of weather prevalence on sigatoka disease of banana suckers in different areas of Bangladesh and to develop an environment friendly disease management practice. Four locations viz. Dinajpur, Bogra, Rangpur and Madhupur were surveyed. To find out suitable and ecofriendly management practices for controlling sigatoka disease of banana, seven treatments were used viz. i) Soil drenching with BAU- Biofungicide (2\%), ii) BAU-Biofungicide as foliar spray (2\%), iii) Soil drenching with BAU-Biofungicide (2\%) plus foliar spray (2\%), iv) Bavistin (carbendazim) spray (0.2\%), v) Dithane M-45 (mancozeb) spray (0.2\%), vi) Soil drenching with BAU-Biofungicide (2\%) plus Bavistin spray $(0.2 \%)$; and vii) control. The average highest incidence $(26.42 \%)$ and severity $(22.84 \%)$ of sigatoka disease of banana suckers were recorded during October at Bogra, while the lowest incidence $(9.75 \%)$ and severity $(8.51 \%)$ were recorded during January at Dinajpur. Out of the control measures employed, BAU-Biofungicide (2\%) either alone or in combination with Bavistin $(0.2 \%)$ was found as an excellent biocontrol means for controlling sigatoka disease of banana suckers.
\end{abstract}

Keywords: Banana sucker, sigatoka disease, eco-friendly management, BAU-Biofungicide

\section{Introduction}

Bananas (Musa spp. L.) are monocotyledonous plants that belong to the family Musaceae and the genus Musa originated in Southeast Asia (Ploetz, 2001). It is one of the most important fruits in the world and is widely grown in the tropical and sub-tropical countries (Simmonds and Shepherd, 1955). Banana is grown over 120 countries worldwide (Thangavelu and Mustaffa, 2012) covering about 10 million hectares with an annual world production estimated at 127 million tons. In Bangladesh, it is grown throughout the year but the production is still low as compared to other banana producing countries of the world (FAO, 2008). Bangladesh produced 414000 tons of bananas in 53609 hectares of land (BBS, 2012). Bananas supply an appreciable amount of vitamins and minerals. One hundred gram of edible portion of banana contains $70 \%$ water, $27 \%$ carbohydrate, $0.5 \%$ fiber, $1.2 \%$ protein, $0.3 \%$ fat, $0.9 \%$ ash, 290 ppm phosphorus, 80 ppm calcium, 6 ppm iron, $0.58 \mathrm{ppm}, \beta$ carotene, $0.5 \mathrm{ppm}$ riboflavin, $7.0 \mathrm{ppm}$ Niacin and 120 ppm ascorbic acid (Haque, 2001). Banana is the major important fruit crops in Bangladesh due to its calorific and nutritive values and of their versatile use by the consumers. 
Success of an orchard depends on the quality of the planting materials. The climate of Bangladesh harbors plant pathogen and provides luxuriant environment for the growth and reproduction of large number of plant pathogens which cause hundreds of different diseases of crops (Fakir, 2001). Determining the effect of weather parameters on the formation, release and germination of inoculum in different pathosystems have been focused by many researchers in worldwide (Pinkerton et al., 1998; MacHardy et al., 2001; Mondal and Timmer, 2002). Plant disease play an important role in reducing yield of horticultural crops in the tropics. It has been estimated that production could be increased at least by $28 \%$ if the crop could be confined against various diseases and many of these diseases have been reported to be transmitted through the planting material (Rawal, 1990).

Banana is grown widely in Bangladesh. However, sigatoka disease of banana suckers has not been thoroughly investigated here. Little information is available about the presence, prevalence, epidemiology and management of sigatoka disease of banana in Bangladesh, although the disease poses a potential threat to seedlings of fruit species by causing enormous loss in plant quality and disruption of production schedules. Therefore, it is necessary to investigate banana field to asses the incidence, severity, epidemiology and management of the pathogen that causes sigatoka disease. The present study was therefore, undertaken to investigate the effects of temperature, rainfall and humidity on the sigatoka disease of banana suckers and to suggest an eco-friendly management package for the disease.

\section{Materials and Methods}

\subsection{Study sites}

Major growing areas of banana were identified and selected based on information gathered from government and non-government organizations. Twenty banana fields in four locations of Dinajpur, Rangpur, Bogra and Madhupur were surveyed and sigatoka disease of banana suckers was observed.

\subsection{Isolation of causal organism}

Suckers of banana were observed carefully and symptoms of the disease were recorded following the description of Ploetz et al. (1998). Diseased samples were collected and brought to the laboratory and the samples were washed thoroughly under running tap water and surface was sterilized with $4 \% \mathrm{NaOCl}$. The diseased parts were then cut into $1.0 \mathrm{~cm}$ long pieces. One set of the pieces was placed on three layers of wet blotters equidistantly in Pyrex plates and another set was placed on PDA medium. Both sets were incubated for 7 days under $12 / 12 \mathrm{hr}$. alternate cycles of near ultra violet light and darkness at $22 \pm 2^{\circ} \mathrm{C}$. The plates were checked after 3 days for fungal growth and continued for 7 days. After incubation, the inoculated PDA plates were observed to identify the causal organisms.

\subsection{Survey on sigatoka disease of banana suckers}

Four visits were made as per locations and growing areas of banana in Bangladesh over a period of one year and the study was carried out during July 2010 to April 2012. In each banana field, 30 suckers were considered for disease incidence and severity. Moreover, meteorological data on temperature, rainfall and relative humidity were collected from weather yards located at Dinajpur, Rangpur, Bogra and Tangail throughout the study period.

\subsection{Assessment of disease incidence and severity}

Percent Disease Incidence (PDI) was calculated using the formula of Rai and Mamatha (2005) and Percent Disease severity (PDS) was calculated using the formula of Johnston (2000) as:

Percent disease incidence $(\mathrm{PDI})=$ Number of diseased leaves on each plant

Number of total leaves on each plant

Percent disease severity $($ PDS $)=$ Area of leaf tissue infected by disease Total area of leaf 


\subsection{Eco-friendly disease management trial} The study was conducted at the Field of the Department of Plant Pathology, Bangladesh Agricultural University, Mymensingh during July 2010 to April 2012.

\subsubsection{Preparation of pits}

Pits were prepared in the field as per method of Mondal (2000). Fertilizers and manures were applied following Fertilizer Recommendation Guide of Bangladesh Agricultural Research Council.

\subsubsection{Treatments}

The experiment was laid out in a Randomized Completely Block Design (RCBD) with three replications and 15 suckers per treatment were used. For the management of sigatoka disease of banana suckers seven different treatments were employed on the variety Amritsagor. Two fungicides viz. Bavistin (carbendazim) and Dithane M-45 (mancozeb) and one Trichoderma based preparation known as BAU-Biofungicide were used for the management of sigatoka disease. The fungicides were used as foliar spray at 30 days interval but BAU-Biofungicide used as foliar spray as well as soil drenching. The treatments were as $\mathrm{T}_{1}=$ Soil drenching with BAU-Biofungicide (2\%), $\mathrm{T}_{2}=$ BAUBiofungicide as foliar spray $(2 \%), \mathrm{T}_{3}=$ Soil drenching with BAU-Biofungicide plus foliar spray $(2 \%), \mathrm{T}_{4}=$ Bavistin spray $(0.2 \%), \mathrm{T}_{5}=$ Dithane M-45 spray $(0.2 \%), \mathrm{T}_{6}=$ Soil drenching with BAU-Biofungicide (2\%) and Bavistin spray $(0.2 \%)$ and $\mathrm{T}_{7}=$ Untreated control.

\subsubsection{Application of bio-agent}

BAU Bio-fungicide is a formulated product of Trichoderma harzianum developed in Ecofriendly Disease Management Laboratory, Department of Plant Pathology, Bangladesh Agricultural University, Mymensingh (Hossain, 2003). BAU Bio-fungicide was thoroughly mixed with the soil @ $6.4 \mathrm{~g} / \mathrm{m}^{2}$ soil (Lo et al., 1996).

2.5.4. Assessment of disease incidence, severity and disease reduction over control
Assessment of incidence and severity of sigatoka disease were done by using the formulae described in 2.4. Percent disease reduction (PDR) was calculated by using the formula of Rai and Mamatha (2005).

\subsubsection{Data analysis}

Collected data on different parameters were compiled and analyzed statistically. Duncan's Multiple Range Test (DMRT) was performed to determine the level of differences and to separate the means within the parameter by using the computer software program MSTAT-C (Russell, 1986)

\section{Results and Discussion}

It was revealed that sigatoka was the most common disease in the banana suckers. The first symptom of sigatoka appeared as minute yellowish green flecks on the third or fourth leaf from the top of the plant. These flecks elongated to narrow yellowish green to yellow streaks (Picture 1.; A and B). The causal organism of sigatoka disease was identified as Cercospora musae from the diseased leaves of banana suckers (Picture 1. C). Conidiophores were pale, straight often bottle shaped and lack septa. The conidiophores apex was round and lack conspicuous scars. Conidia were borne terminally and singly. They were pale, smooth, straight, multicellular and cylindrical. The findings of the present study have been supported by Fullerton et al. (1990).

\subsection{Incidence and severity of sigatoka disease of banana suckers at different locations of Bangladesh}

A great variation was observed in the incidence and severity of sigatoka disease of banana from one counting to another as well as one location to another. Significant variation in relation to incidence and severity of sigatoka disease of banana suckers were recorded that ranged from $12.70-20.78 \%$ and $10.79-18.83 \%$ in $2010-2011$ (Table 1). The highest incidence and severity were recorded at Bogra and the lowest incidence and severity were observed at Dinajpur. But in 
2011-2012, the highest incidence was recorded at Rangpur and the lowest was observed at Dinajpur. Similar trend was also observed in severity of sigatoka disease of banana suckers in 2011-2012. This might be due to the effects of weather factors. The findings of the study are supported by Pathak (1989). In a survey carried out by Hossain (2011) also reported that sigatoka was the most important disease of banana suckers.

3.2. Incidence and severity of sigatoka disease of banana suckers at different time of the year In 2010-2011, incidence and severity of sigatoka disease of banana suckers varied significantly during July 2010 to April 2011 that ranged from 12.57-22.79\% and 11.00-19.33\% (Table 2). The highest incidence and severity were recorded during October 2010 and the lowest incidence and severity were recorded in January 2011. Similar trend was also observed in sigatoka disease incidence and severity of banana suckers in 2011-2012. The results are in agreement with Hossain (2011).

\subsection{Incidence and severity of sigatoka disease of banana suckers at different times and locations of Bangladesh}

In 2010-2011, incidence of sigatoka disease of banana suckers varied significantly from season to season as well as location to location and that ranged from $10.4027 .05 \%$ (Table 3 ). The highest incidence $(27.05 \%)$ was recorded in October 2010 at Bogra while the lowest incidence $(10.40 \%)$ was recorded in January 2011 at Dinajpur. The severity of sigatoka disease also varied significantly from season to season as well as location to location that ranged from $8.60-22.29 \%$. The highest severity was recorded in October 2010 at Bogra and the lowest severity was recorded in January 2011 at Madhupur preceded by January and April 2011 at Dinajpur. Similar trend was also observed in 2011-2012.
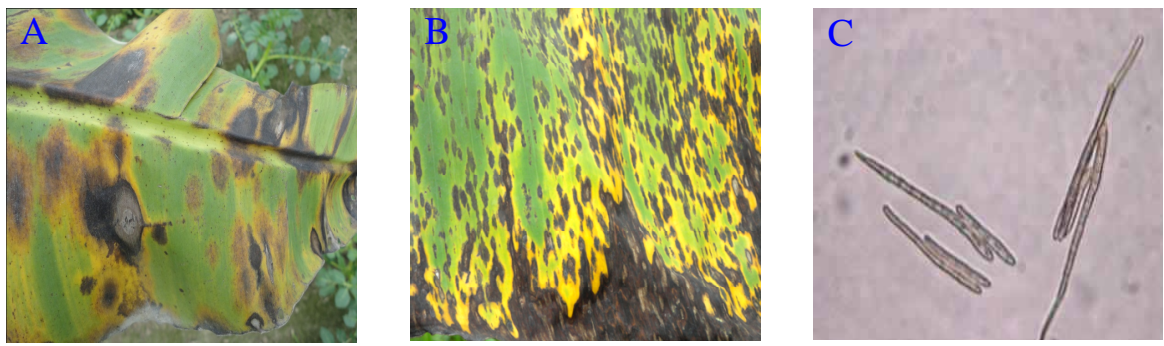

Picture 1. $\mathrm{A}$ and $\mathrm{B}=$ Symptom of sigatoka disease of banana and $\mathrm{C}=$ Conidia of Cercospora musae

Table 1. Incidence and severity of sigatoka disease of banana suckers at different locations of Bangladesh during July 2010 to April 2012

\begin{tabular}{lcccc}
\hline \multirow{2}{*}{ Locations } & \multicolumn{2}{c}{$2010-2011$} & \multicolumn{2}{c}{$2011-2012$} \\
\cline { 2 - 5 } & \multicolumn{2}{c}{ Sigatoka } & Sigatoka \\
\cline { 2 - 5 } & Incidence $(\%)$ & Severity (\%) & $12.33 \mathrm{~d}$ & Severity (\%) \\
\hline Dinajpur & $12.70 \mathrm{~d}$ & $10.79 \mathrm{c}$ & $16.85 \mathrm{~b}$ & $11.68 \mathrm{~d}$ \\
Bogra & $20.78 \mathrm{a}$ & $18.83 \mathrm{a}$ & $17.59 \mathrm{a}$ & $15.08 \mathrm{~b}$ \\
Rangpur & $15.39 \mathrm{c}$ & $15.00 \mathrm{~b}$ & $15.12 \mathrm{c}$ & $12.83 \mathrm{c}$ \\
Madhupur & $17.39 \mathrm{~b}$ & $14.93 \mathrm{~b}$ & 6.84 & 5.52 \\
\hline $\mathrm{CV}(\%)$ & 6.87 & 6.59 & & \\
\hline
\end{tabular}

In a column, figures having same letter(s) do not differ statistically at $5 \%$ level of significance by DMRT. Each data represent the mean value of five nurseries. 
Table 2. Incidence and severity of sigatoka disease of banana suckers at different times during July 2010 to April 2012

\begin{tabular}{lcccc}
\hline \multirow{2}{*}{ Times (Month) } & \multicolumn{2}{c}{$2010-2011$} & \multicolumn{2}{c}{ S011-2012 } \\
\cline { 2 - 5 } & \multicolumn{2}{c}{ Sigatoka } & Incidence (\%) & Severity (\%) \\
\cline { 2 - 5 } & Incidence (\%) & Severity (\%) & $14.03 \mathrm{~b}$ & $12.34 \mathrm{~b}$ \\
July & $16.54 \mathrm{~b}$ & $15.25 \mathrm{~b}$ & $22.84 \mathrm{a}$ & $21.33 \mathrm{a}$ \\
October & $22.79 \mathrm{a}$ & $19.33 \mathrm{a}$ & $11.09 \mathrm{c}$ & $9.60 \mathrm{~d}$ \\
January & $12.57 \mathrm{~d}$ & $11.00 \mathrm{~d}$ & $13.93 \mathrm{~b}$ & $11.93 \mathrm{c}$ \\
April & $14.37 \mathrm{c}$ & $13.95 \mathrm{c}$ & 6.84 & 5.52 \\
\hline $\mathrm{CV}(\%)$ & 6.87 & 6.59 & & \\
\hline
\end{tabular}

In a column, figures having same letter (s) do not differ statistically at 5\% level of significance by DMRT. Each data represent the mean value of five nurseries.

Table 3. Incidence and severity of sigatoka disease of banana suckers at different times and locations of Bangladesh during July 2010 to April 2012

\begin{tabular}{llcccc}
\hline \multirow{2}{*}{ Location } & Time (Month) & \multicolumn{2}{c}{$2010-2011$} & \multicolumn{2}{c}{$2011-2012$} \\
\cline { 3 - 5 } & & \multicolumn{2}{c}{ Sigatoka } & \multicolumn{2}{c}{ Sigatoka } \\
\cline { 3 - 5 } & & 11.501 & $10.20 \mathrm{i}$ & $11.40 \mathrm{i}$ & $9.93 \mathrm{i}$ \\
\cline { 2 - 5 } Dinajpur & July & $16.23 \mathrm{~h}$ & $14.26 \mathrm{~g}$ & $19.42 \mathrm{~d}$ & $20.32 \mathrm{c}$ \\
& October & $10.40 \mathrm{n}$ & $8.87 \mathrm{k}$ & $9.09 \mathrm{j}$ & $8.14 \mathrm{k}$ \\
& January & $12.66 \mathrm{k}$ & $9.81 \mathrm{k}$ & $9.42 \mathrm{j}$ & $8.31 \mathrm{k}$ \\
& April & $16.50 \mathrm{~g}$ & $15.80 \mathrm{f}$ & $15.91 \mathrm{f}$ & $14.38 \mathrm{e}$ \\
Bogra & July & $27.05 \mathrm{a}$ & $22.29 \mathrm{a}$ & $25.79 \mathrm{a}$ & $23.38 \mathrm{a}$ \\
& October & $17.36 \mathrm{f}$ & $16.67 \mathrm{e}$ & $11.54 \mathrm{i}$ & $10.36 \mathrm{~h}$ \\
& January & $22.23 \mathrm{~d}$ & $20.55 \mathrm{~b}$ & $14.17 \mathrm{~g}$ & $12.21 \mathrm{f}$ \\
& April & $15.30 \mathrm{i}$ & $16.60 \mathrm{e}$ & $18.83 \mathrm{e}$ & $16.19 \mathrm{~d}$ \\
Rangpur & July & $23.69 \mathrm{c}$ & $20.22 \mathrm{c}$ & $24.04 \mathrm{~b}$ & $21.42 \mathrm{~b}$ \\
& October & $11.21 \mathrm{~m}$ & $9.86 \mathrm{j}$ & $11.87 \mathrm{i}$ & $10.36 \mathrm{~h}$ \\
& January & $11.37 \mathrm{~lm}$ & $12.96 \mathrm{~h}$ & $15.60 \mathrm{f}$ & $14.46 \mathrm{e}$ \\
& April & $14.18 \mathrm{j}$ & $13.20 \mathrm{~h}$ & $13.22 \mathrm{~h}$ & $10.60 \mathrm{~h}$ \\
Madhupur & July & $24.18 \mathrm{~b}$ & $20.56 \mathrm{~b}$ & $22.10 \mathrm{c}$ & $20.20 \mathrm{c}$ \\
& October & $11.15 \mathrm{~m}$ & $8.60 \mathrm{k}$ & $11.87 \mathrm{i}$ & $9.53 \mathrm{j}$ \\
& January & $20.05 \mathrm{e}$ & $17.69 \mathrm{~d}$ & $13.29 \mathrm{~h}$ & $11.00 \mathrm{~g}$ \\
\hline CV (\%) & April & 6.87 & 6.59 & 6.84 & 5.52 \\
\hline
\end{tabular}

In a column, figures having same letter (s) do not differ statistically at 5\% level of significance by DMRT. Each data represent the mean value of five nurseries.

\subsection{Effects of weather factors on the incidence and severity of sigatoka disease of banana suckers}

Effects of different weather factors (temperature, rainfall and relative humidity) on the incidence and severity of sigatoka disease of banana suckers were studied during July 2010 to April 2012. In 2010-2011. Figure 1 shows that the highest temperature prevailed during July (29.28 ${ }^{\circ} \mathrm{C}$ ) and an equable temperature prevailed during 
August to September. A fall of temperature was observed during October $\left(25.20^{\circ} \mathrm{C}\right)$ to the end of December $\left(18.40{ }^{\circ} \mathrm{C}\right)$ and the coolest period prevailed during January $\left(14.54^{\circ} \mathrm{C}\right)$. About $80 \%$ annual rainfall occurred during the monsoon (late May to mid October). April was the least humid month while the average relative humidity was 78.08, 76.42, 79.58 and $79.25 \%$ in Dinajpur, Bogra, Rangpur and Madhupur, respectively. The relative humidity during June to October was above $80 \%$ and during November to February was $75 \%$. In 2011-12, the weather parameters showed the similar trend as previous year. Based on the analysis of weather parameters four disease recording times were selected to observe the effect of weather on incidence and severity of sigatoka disease of banana suckers. The highest incidence (22.84\%) and severity $(21.33 \%)$ were recorded during the month of October 2011 at temperature, rainfall and relative humidity of $27.18^{\circ} \mathrm{C}, 54.80 \mathrm{~mm}$ and $79.83 \%$, respectively (Figure 1). On the other hand, the lowest incidence (11.09\%) and severity $(9.60 \%)$ were recorded during the month of January 2012 at temperature, rainfall and relative humidity of $17.38^{\circ} \mathrm{C}, 14.75 \mathrm{~mm}$ and $77.25 \%$, respectively. These results are in agreement with that reported by Hossain (2011).

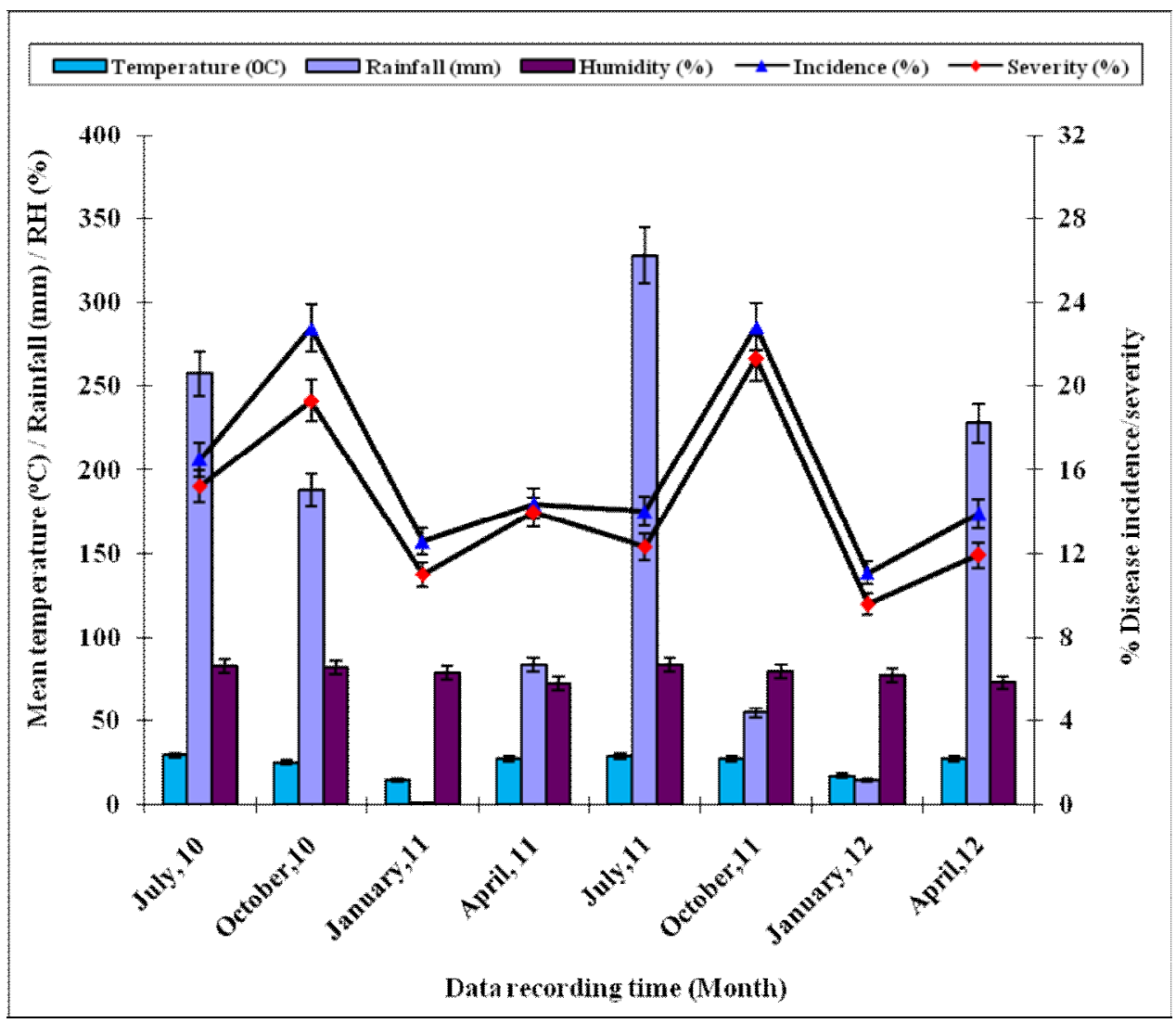

Figure 1. Effcet of weather factors on the incidence and severity of sigatoka leafspot of banana 
Table 4. Correlation and linear regression analysis of temperature, rainfall and relative humidity on the incidence and severity of sigatoka disease of banana suckers

\begin{tabular}{lcccccc}
\hline Weather factors & \multicolumn{2}{c}{$\begin{array}{c}\text { Coefficient of Correlation } \\
(\mathrm{r})\end{array}$} & \multicolumn{2}{c}{ Slope (b) } & \multicolumn{2}{c}{$\begin{array}{c}\text { Coefficient of } \\
\text { Determination }\left(\mathrm{R}^{2}\right)\end{array}$} \\
\cline { 2 - 6 } & Incidence & Severity & Incidence & Severity & Incidence & Severity \\
\hline Temperature & 0.43 & 0.26 & 2.53 & 1.83 & & \\
Rainfall & 0.28 & 0.23 & 0.049 & 0.03 & $0.82^{* *}$ & $0.80^{* *}$ \\
Relative humidity & 0.02 & 0.02 & 0.53 & 0.48 & & \\
\hline
\end{tabular}

Table 5. Effects of different management practices on the incidence and severity of sigatoka disease of banana suckers during July 2010 to June 2012

\begin{tabular}{ccccccccc}
\hline \multirow{2}{*}{$\begin{array}{c}\text { Treat } \\
\text { ments }\end{array}$} & \multicolumn{2}{c}{ Incidence (\%) } & \multicolumn{3}{c}{ \% reduction over control } & \multicolumn{2}{c}{ Severity (\%) } & \% reduction over control \\
\cline { 2 - 9 } & $2010-$ & $2011-$ & $2010-$ & $2011-2012$ & $2010-$ & $2011-$ & $2010-$ & $2011-$ \\
& 2011 & 2012 & 2011 & & 2011 & 2012 & 2011 & 2012 \\
\hline $\mathrm{T}_{1}$ & $24.76 \mathrm{bc}$ & $18.91 \mathrm{bc}$ & 27.92 & 30.71 & $27.64 \mathrm{~b}$ & $10.63 \mathrm{~b}$ & 36.17 & 68.49 \\
$\mathrm{~T}_{2}$ & $21.40 \mathrm{~cd}$ & $15.64 \mathrm{~cd}$ & 37.70 & 42.69 & $22.01 \mathrm{~cd}$ & $4.84 \mathrm{de}$ & 49.17 & 85.65 \\
$\mathrm{~T}_{3}$ & $18.55 \mathrm{~d}$ & $13.47 \mathrm{de}$ & 45.99 & 50.64 & $18.94 \mathrm{~d}$ & $4.14 \mathrm{ef}$ & 56.26 & 87.73 \\
$\mathrm{~T}_{4}$ & $20.42 \mathrm{~cd}$ & $17.36 \mathrm{c}$ & 40.55 & 36.39 & $20.91 \mathrm{~d}$ & $4.95 \mathrm{~d}$ & 51.71 & 85.32 \\
$\mathrm{~T}_{5}$ & $20.06 \mathrm{~cd}$ & $18.28 \mathrm{c}$ & 41.60 & 33.02 & $21.51 \mathrm{~d}$ & $5.34 \mathrm{~cd}$ & 50.32 & 84.17 \\
$\mathrm{~T}_{6}$ & $17.62 \mathrm{~d}$ & $11.77 \mathrm{e}$ & 48.70 & 56.87 & $18.60 \mathrm{~d}$ & $3.79 \mathrm{f}$ & 57.04 & 88.76 \\
$\mathrm{~T}_{7}$ & $34.35 \mathrm{a}$ & $27.29 \mathrm{a}$ & - & - & $43.30 \mathrm{a}$ & $33.73 \mathrm{a}$ & - & - \\
\hline $\mathrm{CV}(\%)$ & 9.11 & 10.17 & - & - & 7.88 & 8.19 & - & - \\
\hline
\end{tabular}

Data represent the mean value of 3 replications; each replication was derived from 15 plants per treatments; in a column means having similar letter(s) are statistically similar at $5 \%$ level of significance by DMRT.

Treatments, $\mathrm{T}_{1}=$ Soil drenching with BAU-Biofungicide (2\%); $\mathrm{T}_{2}=\mathrm{BAU}-$ Biofungicide as foliar spray $(2 \%) ; \mathrm{T}_{3}=$ Soil drenching with BAU-Biofungicide $(2 \%)+$ foliar spray $\left(2 \% ; \mathrm{T}_{4}=\right.$ Bavistin spray $(0.2 \%)$ $\mathrm{T}_{5}=$ Dithane M-45 spray $(0.2 \%) ; \mathrm{T}_{6}=$ Soil drenching with BAU-Biofungicide $(2 \%)+$ Bavistin spray $(0.2 \%)$ and $\mathrm{T}_{7}=$ Control (Untreated)

\subsection{Relationship between weather factors and incidence as well as severity of sigatoka disease of banana suckers}

Correlation and linear regression analysis were performed to determine the relationship between weather factors (temperature, rainfall and relative humidity) and incidence as well as severity of sigatoka disease of banana suckers. It was revealed that incidence and severity were positively correlated with temperature $(\mathrm{r}=0.43$, $\mathrm{r}=0.26)$ and rainfall $(\mathrm{r}=0.28, \mathrm{r}=0.23)$ in both years. On the other hand, incidence $(r=0.02)$ and severity $(\mathrm{r}=0.02)$ were positively and poorly correlated with relative humidity (Table 4 ). The results are in agreement with the findings of
Khan and Hossain (2013). They reported that occurrence of seedling diseases were significantly influenced by temperature, rainfall and relative humidity. Jacome et al. (1991) reported that leaf wetness duration had a major effect on symptom appearance which was delayed up to 14 days when no leaf wetness was present. The delay may be associated with a longer water absorption period required for conidial germination. Conidia germinates at 20$35^{\circ} \mathrm{C}$ over a wide range $(92-100 \%)$ of relative humidity in less than $24 \mathrm{hrs}$. Because, infection by conidia occurred even with no leaf wetness and when the relative humidity was high. The periods of high relative humidity may be 
important for infection when duration of leaf wetness or a rain even is short or absent. Therefore, conidial infection may play an important role in the epidemiology of sigatoka during the dry season when humidity is the limiting factor for infection.

Maximum ascospores germination and growth on the leaf surface have been observed when a film of water is present (Stover and Simmonds, 1987). Thus, the greatest impact of ascospores as source of inoculum may be during the rainy season. Ascospore discharge and infection are less likely during the dry season.

The optimum range of temperature for disease development was $25-28{ }^{\circ} \mathrm{C}$. Temperature did not cause any major effect on the number of lesions, except at $31{ }^{\circ} \mathrm{C}$. Thus, differences in disease severity at a given temperature, among leaves and leaf wetness levels were primarily due to lesion expansion. Lesion size may be dependent on lesion number. Ricker et al. (1985) observed larger lesion size at lower inoculum densities of Cercospora arachidicola. Effects of temperature, rainfall, relative humidity, sun shine hour and leaf wetness on the incidence and severity of disease in different pathosystems have been reported by many researchers (MacHardy et al., 2001; Mondal and Timmer, 2002; Chowdhury and Hossain, 2011). Similar prevalence of sigatika disease caused by Cercospora musae (Akter, 2011) and black sigatoka disease caused by Mycosphaerella fijiensis in banana (Jacome and Schuh, 1992) had been reported to be influenced by excessive rain, humidity and temperature. However, warm temperature (25-28 $\left.{ }^{\circ} \mathrm{C}\right)$, rainfall, leaf wetness and high humidity $(>92 \%)$ can be important parameters in predicting the likelihood of sigatoka disease outbreak .

\subsection{Eco-friendly disease management trial}

BAU-Biofungicide and two other fungicides viz. Bavistin and Dithane M-45 were applied in the field of banana for controlling sigatoka disease. The highest incidence (34.35 and $27.29 \%$, respectively) of sigatoka disease in banana suckers was recorded in untreated control $\left(\mathrm{T}_{7}\right)$ and the lowest (17.62 and $11.77 \%$, respectively) was recorded when BAUBiofungicide was drenched in soil @ $2 \%$ and Bavistin was used as foliar spray @ $0.2 \%\left(\mathrm{~T}_{3}\right)$. The highest reduction $(48.70$ and $56.87 \%$, respectively) of disease incidence was recorded over control when BAU-Biofungicide drenched in soil @ $2 \%$ and Bavistin used as foliar spray @ $0.2 \%$ in both years (Table 5). The lowest reduction of incidence (27.92 and $30.71 \%$, respectively) was recorded over control when only BAU-Biofungicide drenched in soil @ $2 \%$ $\left(\mathrm{T}_{1}\right)$. The highest severity (43.90 and $33.73 \%$, respectively) of sigatoka disease was observed in untreated control and the lowest severity (18.60 and $3.79 \%$, respectively) was observed in BAUBiofungicide drenched in soil @ $2 \%$ and Bavistin used as foliar spray @ $0.2 \%\left(\mathrm{~T}_{6}\right)$ which resulted the highest reduction of (57.04 and $88.76 \%$, respectively) severity over control in both years (Table 5). The lowest reduction of (36.17 and $68.49 \%$, respectively) severity over control was recorded when BAU-Biofungicide applied @ $2 \%$ as soil drench $\left(\mathrm{T}_{1}\right)$ in both years.

Application of BAU Bio-fungicide as soil drench @ 2\% and Bavistin used as foliar spray @ 0.2\% $\left(\mathrm{T}_{6}\right)$ resulted maximum reduction of incidence and severity followed by BAU-Biofungicide drenched in soil as well as used as foliar spray @ $2 \%\left(\mathrm{~T}_{3}\right)$ compared to control. The findings of the present study are also agreement with that report by Akter (2011). She reported that BAUBiofungicide was effective for controlling sigatoka disease of banana. Among the chemicals, Bavistin $(0.2 \%)$ as foliar spray was also found good when incorporated with BAUBiofungicide as soil drenching for controlling sigatoka disease of banana suckers. The findings have been supported by Anaso and Olatunde (1989), Huq et al. (1994) and Prasadji et al. (2004).

\section{Conclusions}

The weather parameters have profound and significant effect on the prevalence of sigatoka 
disease of banana suckers. Out of the control measures employed, BAU-Biofungicide (2\%) either alone or in combination with Bavistin $(0.2 \%)$ was found as an excellent biocontrol means for controlling sigatoka disease of banana suckers. Trichoderma harzianum based BAUBiofungicide, a new means of disease control in the banana field could be employed against sigatoka disease of banana in Bangladesh as an eco-friendly disease management tool.

\section{Acknowledgement}

Authors are grateful to PIU-BARC (NATP phase-1), Bangladesh Agricultural Research Council, BARC, Farm gate, Dhaka-1215 for a research grant to Dr. Ismail Hossain (Research grant No. 169).

\section{References}

Akter, H. 2011. Management of nursery diseases of banana and mango. MS thesis, Department of Plant Pathology, Bangladesh Agricultural University, Mymensingh.

Anaso, A. B. and Olatunde, S. A. 1989. Control of yellow sigatoka of banana (Mycosphaerella musicola Leach) by spray of fungicides in Nigeria. Applied Agricultural Research, 4:4, 253-257.

BBS. 2012. Bangladesh. Bangladesh Bureau of Statistics, Statistical Year Book of Bangladesh. Planning Division, Ministry of Planning, Government. of the People's Republic of Bangladesh, Dhaka. Published in August 2013.

Chowdhury, M. S. M. and Hossain, I. 2011. Effects of temperature, rainfall and relative humidity on leaf spot of jackfruit seedling and its eco-friendly management. The Agriculturists, 9 (1\&2): 126-136.

Fakir, G. A. 2001. List of seed borne diseases of important crops occurring in Bangladesh. Department of Plant Pathology, Bangladesh Agricultural University, Mymensingh.
FAO. 2008. Food and Agriculture Organization of the United Nations, Report on Bangladesh Emergency Programme. FAO, Rome, Italy.

Fullerton, R. A. and Stover, R. H. 1990. Sigatoka leaf spot disease of Bananas: Proc. of the International Workshop held on March 28-April 1 at San Jose, Costa Rica.1989. Montpellier, France: INIBAP. 374 pp.

Haque, M. A. 2001. Modern Production Technology of Banana, Horticulture Research Center, BARI, JoydebpurGazipur. 2 p.

Hossain, I. 2003. BAU-Biofungicide, Agricultural Technologies, BAURES, Bangladesh Agricultural University, Mymensingh, Bangladesh. 18 p.

Hossain, I. 2011. Nursery diseases of some selected fruit species in Bangladesh. Ecofriendly Plant Disease Management Laboratory, Department of Plant Pathology. Bangladesh Agricultural University. 8-20 pp.

Huq, M. I., Ahmed, H. U. and Malaker, P. K. 1994. Control of sigatoka of banana with foliar fungicides. Plant Pathology Division, Bangladesh Agricultural Research Institute, Jessore, Bangladesh. 29: 2, 81-85 pp.

Jacome, L. H. and Schuh, W. 1992. Effect of leaf wetness duration and temperature on development of black sigatoka disease on banana infected by Mycosphaerella fijiensis var. difformis. Phytopathology. 82: 515-520.

Jacome, L. H., Schuh, W., and Stevenson, R. 1991. Effect of temperature and relative humidity on germination and germ tube development of Mycosphaerella fijiensis var. difformis. Phytopathology. 81: 14801485.

Johnston, P. R. 2000. The importance of phylogeny in understanding of host relationship within Colletotrichum. In: Prusky D., Dickman, M. B. and Freeman, 
S. (eds). Colletotrichum host specificity, Pathogenicity and host-pathogen interactions. St. Paul, Minnesota: APS Press. 21-28 pp.

Khan, M. A. H. and Hossain, I. 2013. Leaf spot disease of coconut seedling and its ecofriendly management. Journal of the Bangladesh Agricultural University. 11(2): 199-208.

Lo, C. T., Nelson, E. B. and Harman, G. E. 1996. Biological control of turfgrass diseases with a rhizosphere competent strain of Trichoderma harzianum. Plant Disease. 80: 736-741.

MacHardy, W. E., Gadoury, D. M. and Gessler, C. 2001. Parasitic and biological fitness of Venturia inaequalis: relationship to disease management strategies. Plant Disease. 85: 1036-1051.

Mondal, M. F. 2000. Production and Storage of Fruits (in Bangla). Bangladesh Agricultural University, Mymensingh. $312 \mathrm{p}$.

Mondal, S. N. and Timmer, L. W. 2002. Environmental factors affecting pseudothecial development and ascospore production of Mycosphaerella citri, the cause of citrus greasy spot. Phytopathology. 92: 1267-1275.

Pathak, V. N. 1989. Diseases of fruit crops. Oxford \& IBH Publishing Co. Pvt. Ltd. New Delhi, Bombay Calcutta, India. 249$250 \mathrm{pp}$.

Pinkerton, J. N., K. B. Johnson, J. K. Stone and K. L. Ivors. 1998. Factors affecting the release of ascospores of Anisogramma anomala. Phytopathology. 88: 122-128.

Ploetz, R. C. 2001. Black Sigatoka of Banana: The most important disease of a most important fruit. Tropical Research and Education Center, University of Florida, IFAS, Homestead, 11: 1, 19-23.

Ploetz, R. C., Zentmyer, G. A., Nishizima, W. T., Rohrbach, K. G. and Ohr, H. D. 1998.
Compendium of Tropical Fruit Diseases, APS press. The American Phytopathology Society. 34-44 pp.

Prasadji, J. K., Bhagavan, B. V. K., Rao, G. S. and Rao, D. M. 2004. Management of sigatoka and other leaf spots in banana with fungicides. Indian Journal of Plant Protection. 32 (1): 151-153.

Rai, V. R. and Mamtha, T. 2005. Seedling diseases of some important forest tree species and their management. In. Working papers of the Finish Forest Research Institute. $11 \mathrm{p}$.

Rawal, R. D. 1990. Fungal and bacterial diseases of fruit crops. A decade of research on diseases of horticultural crops under AICRIP (1980-1989). Presented at a group discussion of plant pathologists working in coordinated projects of horticulture, held at IIHR during June 1415 .

Ricker, M. D., Beute, M. K. and Campbell, C. L. 1985. Components of resistance in peanut to Cercospora arachidicola. Plant Dis. 69: 1059-1064.

Russell, D. F. 1986. MSTAT-C package programme. Crop and Soil Science Department, Michigan State University, USA.

Simmonds, N. W. and Shepherd, K. 1955. The taxonomy and origins of cultivated bananas. Journal of the Linnean Society ofLondon, Botany 55: 302-312.

Stover, R. H. and Simmonds, N. W. 1987. Bananas. $3^{\text {rd }}$ ed. Longman Scientific \& Technical. 468 p.

Thangavelu, R. and Mustaffa, M. M. 2012. Current advances in the Fusarium wilt disease management in banana with emphasis on biological control. 273-298 pp. In: Christian Joseph R. Cumagun (ed.), Agricultural and Biological Sciences: Plant Pathology, INTECH Publication. 